\title{
Editorial Review of Volume 13
}

\author{
SYLVIA L. THRUPP
}

CSSH has from the start favored writing that probes relationships between different aspects of society. Many of the manuscripts that pile up weekly on the editorial desk concentrate on formal organizational structures, as though the aim of comparative study were just to theorize about social and political morphology. To historians and to social anthropologists, indeed to any observer of the frequent looseness of fit between formal structures and the actual conduct or aspirations of the people involved in them, this would be a somewhat dreary aim. Comparative study can deepen our understanding of the kinds and degrees of such looseness of fit, and of the circumstances in which it may become so exacerbated as to drain away the potency of received beliefs or institutions, making room for new ones.

The 1971 volume is perhaps the most consistently successful in pursuing this more difficult aim. J. N. D. Anderson's paper on current legal reforms in Islamic countries set the appropriate tone by its emphasis on the ambivalence of religious leadership and on the crucial role that the education of women will play in implementing the reforms. Anyone who believes that modernization necessarily liberates women, however, should turn to Sidney Mintz's account of how African economic development is robbing women of the high status that they could formerly attain as merchants. Readers weary of simplistic typologies of traditional society will have welcomed the special April issue on.Tradition. Edward Shils's lead article there, more constructive and penetrating than my own preliminary remarks in review articles in Volumes 4 and 6, is the first in sociological literature to consider the variety of ways in which individuals react to different forms of traditional belief, the variety of purposes these serve, and the patterns of change that they display through time. Milton Singer adds a theoretical plea for going 'Beyond Tradition and Modernity', at least in regard to modern India. R. S. Khare backs Singer's thesis by describing how easily educated modern Indians move between the different social worlds of home and office. Leslie Sklair and Richard Meier then bring us back to Western Europe to discuss the degree of weakening of our own tradition of faith in technology and science. 
The October number returns to the theme of tradition through a search for patterns in the perception of ethnic and cultural differences. Some of the relevant problems were raised in Peter Charanis's article (in Vol. 3) on the Byzantine Empire's treatment of minorities, and in Max Rheinstein's review (in Vol. 2) of the Jean Bodin Society's important books on L'Etranger. Cruel cartooning from New York in the 1880s and 1890s now serves as a springboard for a plunge into late ancient and medieval experience in the formation of Latin Christendom and of Indian civilization through cumulative absorption of new ethnic groups. The evidence our authors survey is the voicing of value judgments by literary spokesmen and the framing of codes setting out proper relationships. Although the persistence of ritual criteria in determining status scales is peculiar to India, readers will find numerous similarities in the juggling of values that occurred in both civilizations when groups formerly considered inferior took positions of power. Sidney Mintz's critique of the Hoetink hypothesis of somatic differences in the perception of shades of skin color is a pertinent addition to this discussion. So also is Denis Goulet's analysis of Western phenomena of marginality, exemplified in detail by the status of gypsies in Spain.

From the many structural studies received two sets were selected that seemed outstanding on grounds of methodological importance and for the intrinsic interest of their subject matter. Those published in January focus on types of struggle for power within contemporary states. Condensing sequential change in strike patterns in France by new graphic techniques, Charles Tilly and Edward Shorter move round the industrialized world to demonstrate the general trend to bigger but briefer strikes. Amal Vinogradov and John Waterbury apply a new method of analyzing the dangers of splintering of power, using the case of Morocco. Leo Kuper argues that class theories of revolution do not adequately explain the predominantly racial struggles in Africa. He will develop his argument further in the next volume.

The summer issue enlarged the scope of our long series of articles on the peasantries of the modern world, the political and religious movements in which their hopes take form, and the severity of the economic problems they face. The most challenging contribution is G. William Skinner's, which attacks the prevalent view that village communities were normally closed off from the rest of a bureaucratically ruled society until political or economic modernization began to affect the countrysides. Unrolling the history of China, he shows that every strong dynasty set off a remarkable wave of expansion that drew peasants into regional trade and launched many of them on upwardly mobile careers as traders or scholars.

Scheduled for publication in July, the summer issue was inevitably somewhat delayed by the British postal strike. The editors are most grateful to our publishers and to our printers for having done everything possible to shorten the delay. 